\title{
Retail Food Waste: Existing Research and Research Gap
}

\author{
Shamsunnahar Khanam ${ }^{1 *}$, Tabassum Sultana ${ }^{2}$, and Zannatul Ferdous ${ }^{3}$ \\ ${ }^{1}$ Associate Professor, Chairman, Department of Environmental Science, Bangladesh University of Professionals (BUP), Bangladesh \\ ${ }^{2}$ Masters Student, Department of Environmental Science, Faculty of Science and Technology, Bangladesh University of Professionals (BUP), Bangladesh \\ ${ }^{3}$ Lecturer, Department of Environmental Science, Bangladesh University of Professionals (BUP), Bangladesh
}

Submission: June 10, 2021; Published: July 08, 2021

*Corresponding author: Shamsunnahar Khanam, Associate Professor, Chairman, Department of Environmental Science, Faculty of Science and Technology, Bangladesh University of Professionals (BUP), Mirpur-12, Dhaka-1216, Bangladesh

\begin{abstract}
Lately, food waste has become an alarming issue because of its negative effects on society and environment. Food waste occurs in every step of supply chain from its harvesting to consumers' plate. Producing retail food waste contributes comparatively less than the consumer waste but it can make potential effects in the society. It has been estimated that every year European Union grocery retails have produced 4.4 million tons of food waste, which is exactly $5 \%$ of the whole food wastage across the European Union food supply chain that is either entirely edible or partially edible. Decomposing food waste produces various types of greenhouse gases, which are one of the reasons of climate change. Different policies are implemented in developed countries like the United Kingdom, Norway and Sweden, for reducing waste and handling the surplus retail food waste. However, policies are absent in a developing country like Bangladesh. Though the reason for retail food waste is constant, the effect is vast and scattered. The aim of this paper is to find out the status of food waste research from a small retail sector but elaborate the academic area of retail food waste by reviewing studies on food waste and clear the factor that nourishes and hampers the generation of food waste in retail level. Moreover, this paper briefly describes some preventive methods that can encourage to reduce waste and also mention some ways of tackling the retail food waste, especially surplus food. The analysis makes a clear view that the reason of retail food waste is quite similar in every aspect and its prevention depends mostly on stakeholders and customers' behavior. At the end of this study, a set of connection shows the relationship between the retail food waste and policy implication.
\end{abstract}

Keywords: Food waste; Retail; Academic area review; Food waste policy

\section{Introduction}

Food waste has become a potential trend and objections that can form the future trajectories of world food and agriculture [1]. Different countries produce different amounts of food waste. The generation of food waste mainly depends on country's revenue, industrialization and how developed the country is [2]. In the food level, waste is a serious issue in communal, nutritional and environmental sectors that can hamper the sustainability of the food chain. In the European Union (EU), they produce 90 million tons of foodwaste each year. Which converts $180 \mathrm{~kg}$ per person [3]. Occurring food waste happened in every supply chain through various characteristics and dictation. According to an extensive study, retail food waste was estimated at 4.6 million tons in 2012 and among this, $5 \%$ of the total food waste came along with the supply chain [4]. The study of food waste in the retail sector are overlooked. The volumes and types of food waste generated in retail have been researched in the past. For example, in Sweden and Switzerland food loss in retail sector was competitively lower than other steps in the food chain [5]. Organic waste was high in departmental level [6]. Though retail level food waste has received comparatively less attention [7], retail level food waste can be effectively reduced in the developed world [8]. The major source of producing food waste from retail level are: impairment of packaging, excess stocking, and over-preparing, these all are connected to the problem of the number of customers at the store [9]. The problem of food waste has been kept in mind when it connects with the flow of "shrinkage", it gives the loophole between backlogs and sales, and this is mainly used as a benchmark of the performance of the retail sector [4]. At retail level, huge amounts of food waste happen in confined areas with a definite number of locations, making a good scope to implement the waste reduction policies that focus on food waste and surplus food [10]. The 
authors emphasized that the surplus food should be donated or use it as animal feed instead of landfilling or incinerating.

But the fact that donating in the charity or giving in the food bank does not change the loss of economic value. Ultimately in a commercial sense monetary loss happens $[1,4]$. In developed countries food waste is usually connected to customer behavior as well as the policies and regulation that address this type of waste [2]. Store level food waste reduction is very challenging for retailer, this needs to improve their efficiency for reducing the amount of food that goes to waste [9]. However, investing money for staff training, carrying environmental, social and economic profit for minimizing food waste can lead to sustainable and organized food waste reduction strategy not only at the retail level but also the whole supply chain [11]. The initial challenge for sustainable food supply chain is to apply fruitful methods to maximize the availability of sustainable things and create awareness among the customers [12].

This paper presents a literature review of current scholarly discussion on statues of retail food waste in an organized, clear and replicable way. This paper also reviews and analyzes the indicator of the reason that prompting retail food waste, based on this reason here also reviewed some of the prevention methods too. Likewise, this study provides some policy approaches that exist for tackling this generations waste. This paper has also identified the gaps and made suggestions for future research.

\section{Methodology of the Study}

This paper reviewed the recently growing body of academic literature on retail waste by observing the systematic literature review. Systematic review can build strong knowledge which will help to solve the managerial problem by generating trusted understanding through this vast range of findings. For scholars, this type of review will be able to increase the methodological diligence and high chances of future research (Schanesa et al., 2018). In this study, firstly selected those literatures which are relevant to the study objectives like the present condition of retail food waste and its causes. Here we have narrowed down the search by omitting the books and 'grey' literature and selecting only those peer-reviewed journal papers which are written in English. Google scholar searched engine has been used for obtaining data from literature. The searching keywords were "Food waste" and "retail". The articles are mainly gathered by analyzing the abstracts and excluded studies that did not focus on retail food waste. The whole methodology has been briefed in the following flow diagram.

Figure 1 shows the overall methods of selecting papers. The key words were obtained from preliminary screening of publication of food waste. And the categories and subcategories took from mainly abstract after reviewing the whole paper. The categories were divided into five segments (Table 1). These are i) Food waste in retail sector; ii) Impact of retail food waste; iii) Reason of retail food waste; iv) Prevention of retail food waste and v) Implementing laws regarding retail food waste.

Table 1: Categories and Sub-categories of Selected Review Paper on Retail Food Waste.

\begin{tabular}{|c|c|c|c|c|c|c|}
\hline Topic & $\begin{array}{l}\text { Food waste in the } \\
\text { retail sector }\end{array}$ & $\begin{array}{l}\text { Impact of retail } \\
\text { food waste }\end{array}$ & $\begin{array}{l}\text { Reason for retail } \\
\text { food waste. }\end{array}$ & $\begin{array}{l}\text { Prevention of retail } \\
\text { food waste. }\end{array}$ & $\begin{array}{l}\text { Tackling method of } \\
\text { surplus retailfood }\end{array}$ & $\begin{array}{l}\text { Implementing laws } \\
\text { regarding retail } \\
\text { foodwaste. }\end{array}$ \\
\hline $\begin{array}{l}\text { Sub- } \\
\text { topic }\end{array}$ & $\begin{array}{l}\text { i) Estimation of } \\
\text { retail food; } \\
\text { ii) Kinds of waste } \\
\text { in retail; } \\
\text { iii)Unrecorded } \\
\text { food waste at } \\
\text { stores. }\end{array}$ & $\begin{array}{l}\text { i) Monetary impact; } \\
\text { ii) Environmental } \\
\text { impact. }\end{array}$ & $\begin{array}{l}\text { i) Perishability; } \\
\text { ii) Employee fault; } \\
\text { iii) Weather } \\
\text { influencing; } \\
\text { iv) Take-back } \\
\text { agreement; } \\
\text { v) Visual } \\
\text { impairments }\end{array}$ & $\begin{array}{l}\text { i) Economic losses } \\
\text { produce motivation; } \\
\text { ii) Proper managerial } \\
\text { interaction. } \\
\text { iii) Environmental con- } \\
\text { cern make it possible } \\
\text { to reduce the amount } \\
\text { of retail waste } \\
\text { iv) Implement laws } \\
\text { and policies for proper } \\
\text { handling of retail food } \\
\text { waste. } \\
\text { v) packaging m } \\
\text { vi) media atten- } \\
\text { tion }\end{array}$ & $\begin{array}{l}\text { i) Donation and ani- } \\
\text { mal feed; } \\
\text { ii) Landfill; } \\
\text { iii) Food redistribu- } \\
\text { tion. } \\
\text { iv) Food recycle }\end{array}$ & $\begin{array}{l}\text { i) Decomposed relat- } \\
\text { ed policies }\end{array}$ \\
\hline
\end{tabular}


Annals of Social Sciences \& Management studies

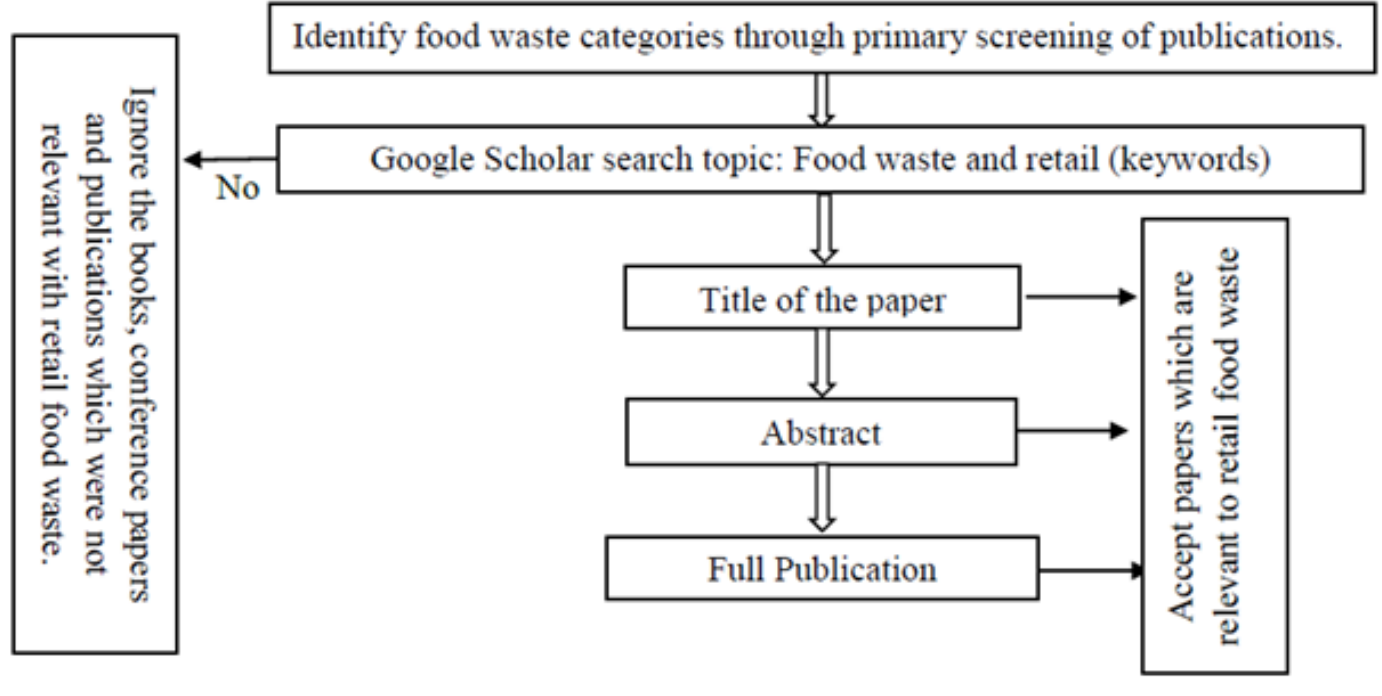

Figure 1: Flow Diagram of Considering Journals.

\section{Analysis of Bibliography}

Here a brief analysis of the articles that are selected for the review has been given. Table 1 showed the number of publications of retail food waste which were found within the year 2011-2020. It has been clearly seen that the academic interest of retail food waste has been increased after 2016.

A possible reason of sudden increase in the number of scholar interest is, in 2014, one of the world's largest food retailers named 'Tesco'- revealed that it had generated almost 57,000 tons of food waste in its UK operations over the last twelve-months. But Tesco released its findings, in 2016, that almost a million people in the UK required the provision of 'emergency food' [13]. So this topic has been highlighted after publishing the findings in 2016. Figure 2 , Tables 2 \& 3 showed an overview of authors' paper publication trend, number of publications and academic journal respectively. Literature review considered the authors who are engaged in the area of food waste in retail sector and the publications. Total 80 authors published 31 different journals. Amongst all these "Resources, Conservation and Recycling" dominated the area and published 8 articles, after that, Journal of "Cleaner Production" published 4 articles.

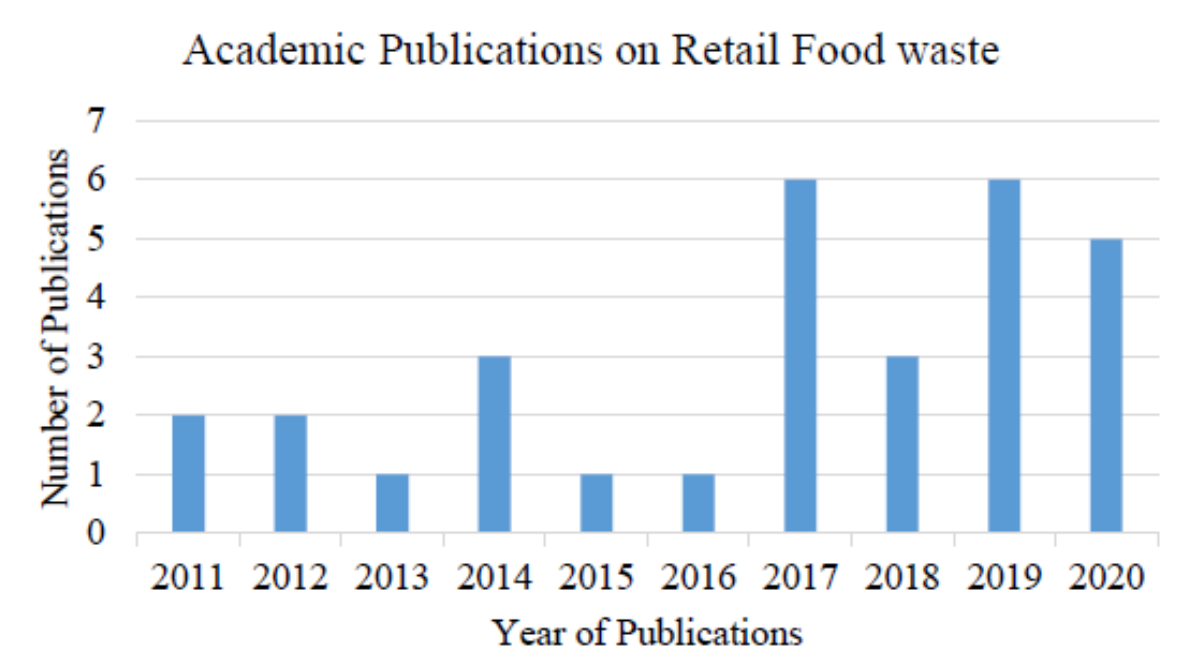

Figure 2: Academic publications on food waste (Retail level). 
Annals of Social Sciences \& Management studies

Table 2: List of authors' numbers of publications regarding retail food waste.

\begin{tabular}{|c|c|c|c|}
\hline Author & Number of publications & Author & Number of publications \\
\hline Eriksson, Strid & 3 & Colombo de Moraes, Henrique de Oliveira Costa & 1 \\
\hline Cicatiello, Franco & 3 & Dreyer, Dukovska Popovska & 1 \\
\hline Chakanikova, Mont & 2 & Filimonau, Gherbin & 1 \\
\hline Audet, Brisebois & 1 & Fehr, Calgado & 1 \\
\hline Albizzati, Tonini & 1 & Ghosh, Eriksson & 1 \\
\hline Brancoli, Lundin & 1 & Goodman-Smith, Mirosa & 1 \\
\hline Chalak, Abou-Daher & 1 & Gustavsson, Stage & 1 \\
\hline Hermsdor, Rombach & 1 & Mondello, Salomone & 1 \\
\hline Lanfranchi, Giannetto & 1 & Rosenlund, Nyblom & 1 \\
\hline Lee & 1 & Soma & 1 \\
\hline Lebersorger, Schneider & 1 & Swaffield, Evans & 11 Publications \\
\hline Marrucci, Marchi & 1 & & Total \\
\hline Mena, Diaz & 1 & & \\
\hline Total & 19 Publications & & 1 \\
\hline
\end{tabular}

Table 3: Top 14 academic journals by the number of publications on retail food waste.

\begin{tabular}{|c|c|}
\hline Academic Journals & Number of Publications \\
\hline 1.Resources, Conservation and Recycling & 8 \\
\hline 2.Journal of Cleaner Production & 4 \\
\hline 3.Waste Management & 3 \\
\hline 4. Journal of Retailing and Consumer Services & 2 \\
\hline 5. British Food Journal & 1 \\
\hline 6. American Journal of Applied Sciences & 1 \\
\hline 7. Sustainability & 1 \\
\hline 8. Procedia Computer Science & 1 \\
\hline 9. International Planning studies & 1 \\
\hline 10.Geoforum & 1 \\
\hline 11.Food Policy & 1 \\
\hline 12.Global Food Security & 1 \\
\hline 13.Food Security & \\
\hline 14. Corporate Social Responsibility and Environmental Management & \\
\hline
\end{tabular}

\section{Results and Discussion}

\section{Context of the Study}

Most of the study on retail food waste was held in the area of Sweden and Italy. Sweden has 8 publications and Italy has 6. After Sweden and Italy, the maximum number of publications were found in the UK and Spain (Table 4). The following subsections discuss the reasons that are working behind the generation of retail food waste and also the preventive measures. So, this study starts the discussion with scholarly evidence that cover most of the parts in order to obtain scopes.

\section{Food Waste in Retail Sector}

Some quantitative study was found on the enumeration of retail food waste $[4,7,14,15]$, kinds of waste in retail -bread [16] fruits and vegetables [17-19], meat and dairy products in different countries [6,7] stated that grocery retail food waste can be categorized into 4 basic divisions: waste generated before storing; in-store recorded waste; in-store unrecorded waste; and quantities that are missing.

Nearly fifty-seven thousand tons of food waste had been generated by UK retailers in one year [13]. Goodman-Smith et al., 2020 argued that the amount per annum is about two hundred 


\section{Annals of Social Sciences \& Management studies}

and ten thousand tons. At the retail stage, EU generates around 4.4 million tons of food which are dumped which indicates $5 \%$ of total food wastage [3]. On the other side, Lebersorger, Schneider [14] pointed that food loss is up to $1.3 \%$ of dairy products sales, $2.8 \%$ for bread and pastries, $4.2 \%$ for vegetables and fruits. Unsold items amount to an additional $9.7 \%$ of bread and pastries sales. According to Dreyer et al. [8], bread, vegetables and meats are among the highest wastes. Fruits and vegetables along with bakery products represented two-thirds of total food waste concerning weight and it was around $25 \%$ in terms of value [4]. The dairy products are also one of the highest wastes [14]. And generally small retail shops produce more waste [18].

Table 4: List of publications on retail food waste with country and author.

\begin{tabular}{|c|c|c|}
\hline Author & Country & Title \\
\hline Albizzati, et al. 2019 & France & $\begin{array}{l}\text { Valorization of surplus food in the French retail sector: Environmental and econom- } \\
\text { ic impacts. }\end{array}$ \\
\hline Audet, et al. & Canada & The Social Production of Food Waste at the Retail- Consumption Interface. \\
\hline Lebersorger, et al.2014 & Austria & $\begin{array}{l}\text { Food loss rates at the food retail, influencing factors and reasons as a basis for } \\
\text { waste prevention measures. }\end{array}$ \\
\hline Brancoli, et al.2019 & Sweden & $\begin{array}{l}\text { Bread loss rates at the supplier-retailer interface - Analysis of risk factors to sup- } \\
\text { port waste prevention measures. }\end{array}$ \\
\hline Chalak, et al. & $\begin{array}{l}33 \text { Developed Countries in } \\
\text { North America }\end{array}$ & $\begin{array}{l}\text { Generation of food waste in the hospitality and food retail and wholesale sectors: } \\
\text { lessons from developed economies. }\end{array}$ \\
\hline Olga, et al.2019 & Europe & Overview of sustainability initiatives in European food retail sector. \\
\hline Cicatiello, et al. 2016 & Italy & The value of food waste: An exploratory study on retailing. \\
\hline Cicatiello, et al. 2017 & Italy & The dark side of retail food waste: Evidence from in- store data. \\
\hline Cicatiello, et al. 2020 & Italy & Disclosure and assessment of unrecorded food waste at retail stores. \\
\hline Dreyer, et al 2019 & Scandinavian Countries & $\begin{array}{l}\text { A ranking method for prioritizing retail store food waste based on monetary and } \\
\text { environmental impacts. }\end{array}$ \\
\hline Eriksson, et al. 2012 & Sweden & $\begin{array}{l}\text { Food losses in six Swedish retail stores: Wastage of fruit and vegetables in relation } \\
\text { to quantities delivered. }\end{array}$ \\
\hline Eriksson, et al. 2014 & Sweden & $\begin{array}{l}\text { Waste of organic and conventional meat and dairy products-A case study from } \\
\text { Swedish retail }\end{array}$ \\
\hline Eriksson, et al. 2017 & Sweden & $\begin{array}{l}\text { Take-back agreements in the perspective of food waste generation at the suppli- } \\
\text { er-retailer interface. }\end{array}$ \\
\hline Filimonau, et al. 2017 & UK & $\begin{array}{c}\text { An exploratory study of food waste management practices in the UK grocery retail } \\
\text { sector. }\end{array}$ \\
\hline Ghosh, et al. 2019 & Sweden & Food waste due to retail power in supply chains: Evidence from Sweden. \\
\hline Goodman-Smith, et al.2020 & New Zealand & A mixed-methods study of retail food waste in New Zealand. \\
\hline Gustavsson, et al. 2011 & Sweden & Retail waste of horticultural products in Sweden. \\
\hline Hermsdor, et al. 2017 & Germany & Food waste reduction practices in German food retail. \\
\hline Lanfranchi, et al. 2014 & Italy & $\begin{array}{l}\text { Analysis and model for the reduction of food waste in organized large-scale retail } \\
\text { distribution in eastern Sicily. }\end{array}$ \\
\hline Lee, et al. 2017 & South Korea & Grocery shopping, food waste, and the retail landscape of cities: the case of Seoul. \\
\hline Marrucci, et al. 2020 & Italy & $\begin{array}{l}\text { Improving the carbon footprint of food and packaging waste management in a } \\
\text { supermarket of the Italian retail sector. }\end{array}$ \\
\hline Mattsson, et al.2018 & Sweden & $\begin{array}{l}\text { Waste of fresh fruit and vegetables at retailers in Sweden - Measuring and calcula- } \\
\text { tion of mass, economic cost and climate impact }\end{array}$ \\
\hline Mena, et al. 2011 & UK and Spain & $\begin{array}{l}\text { The causes of food waste in the supplier-retailer interface: Evidences from the UK } \\
\text { and Spain }\end{array}$ \\
\hline Mondello, et al. 2017 & Italy & $\begin{array}{l}\text { Comparative LCA of Alternative Scenarios for Waste Treatment: The Case of Food } \\
\text { Waste Production by the Mass-Retail Sector }\end{array}$ \\
\hline Rosenlund, et al. 2020 & Sweden & The emergence of food waste as an issue in Swedish retail \\
\hline Soma, et al. 2017 & Indonesia & $\begin{array}{l}\text { Space to waste: the influence of income and retail choice on household food con- } \\
\text { sumption and food waste in Indonesia. }\end{array}$ \\
\hline Swaffield, et al. 2018 & UK & $\begin{array}{l}\text { Profit, reputation and 'doing the right thing': Convention theory and the problem of } \\
\text { food waste in the UK retail sector }\end{array}$ \\
\hline
\end{tabular}




\section{Annals of Social Sciences \& Management studies}

Fruits and vegetables are recorded as the most waste producing category in both mass and value (36\% in weight, $19 \%$ in value) (Figure 3). Bakery food and cold cuts, these two items also represented a vital part for producing food waste at stores, $18 \%$ weight and $19 \%$ in value for bakery food products, $15 \%$ in mass and $16 \%$ in value for cold cuts. While on the other hand, sea food and cooked product value are much higher than its mass. Because the product value is higher than other food products. In terms of value the rate of cooked food waste are (16.3\%), bakery (5.9\%) and fresh seafood (4.3\%), whilst frozen products, groceries and unpacked cold cutsthe rates of food waste was negligible (Figure 4) [9].

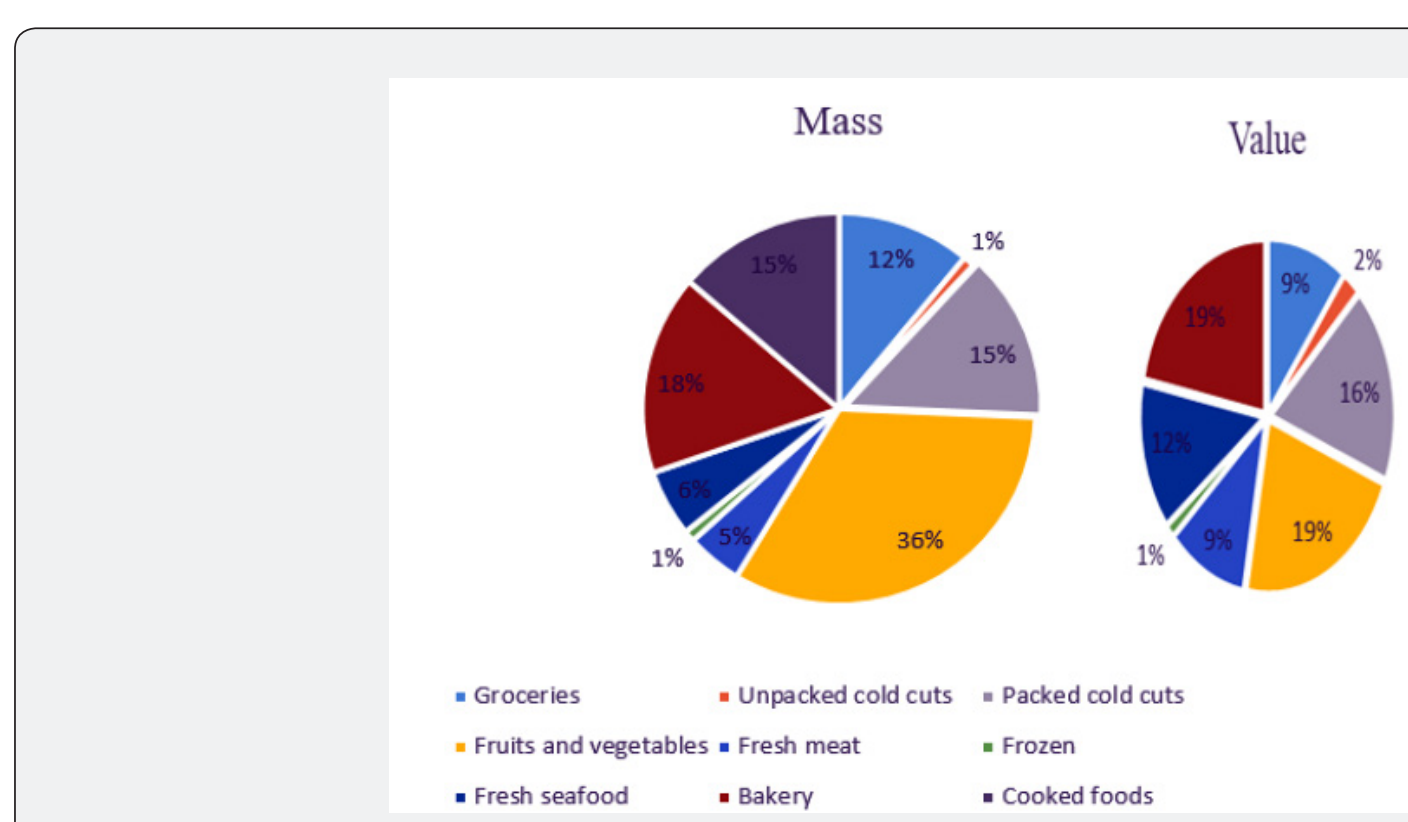

Figure 3: Food waste by department in the panel of stores Source: Cicatiello and Franco, 2020.

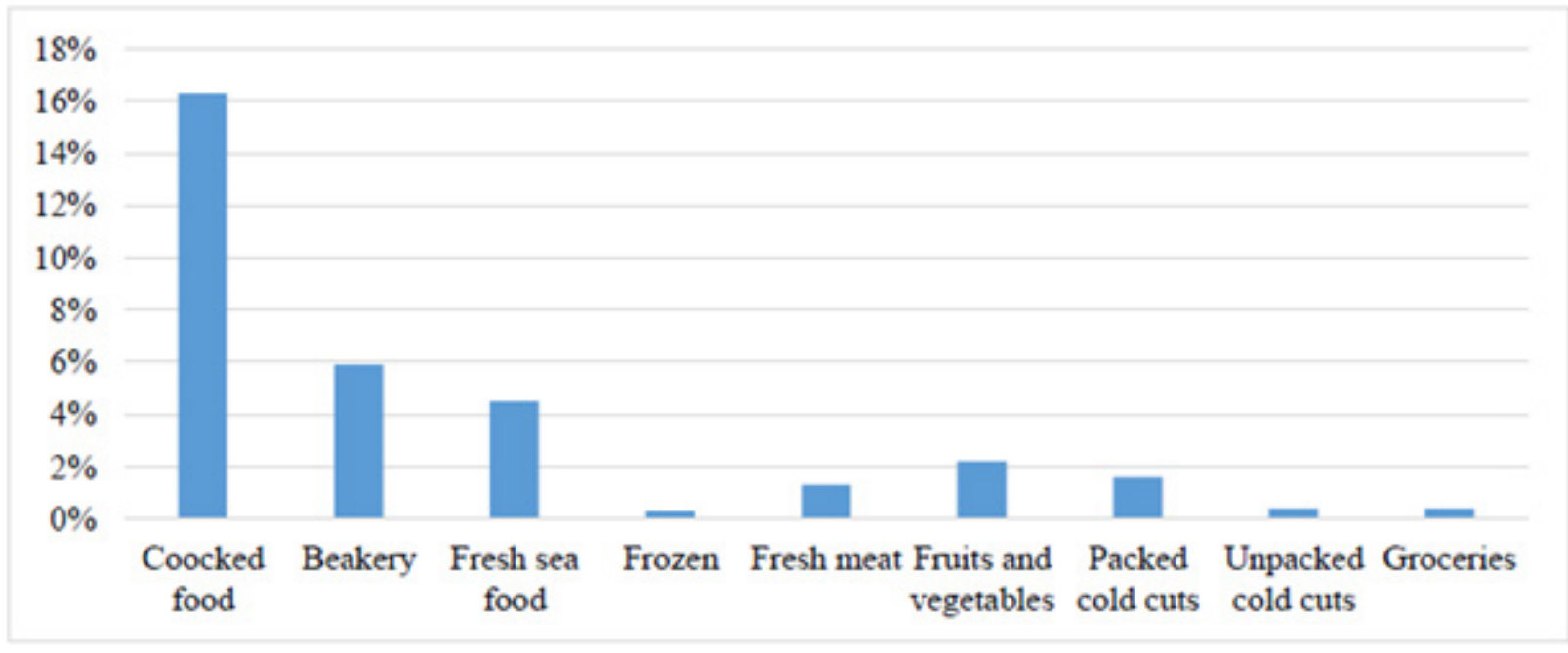

Figure 4: Food waste rates in value by food category. Source: Cicatiello and Franco, 2020.

\section{Unrecorded Food Waste at Stores}

Unrecorded retail food waste becomes a serious concern and takes a specific topic amongst scholarly discussion $[4,6,7,9]$.
There were two actual reasons for unlisted in-store waste: either employees didn't register every wasted item, or they took wrong measurements [17]. The remaining dairy products were not 
added in the store's report because this product was taken back to the suppliers through take-back agreements. At this moment, food was considered as waste, but it shifts in another supply chain [7].

\section{Impact of Retail Food Waste}

Several studies analyzed the impact of retail food waste on financial sector $[8,13,14,17,19]$ and environmental sector $[8,13,16,19,20-22]$. The highest impacted food 'Bread and Bakery' is contributing in both carbon-dioxide emission (in $\mathrm{kg}$ ) and financial loss [8].

Table 5: Product groups according to monetary waste impact.

\section{Monetary Loss}

From a financial point of view, the fruits and vegetables category (causing more than $20 \%$ of monetary value) follows the bread and confectionery category and impacts more than the meat, fish and dairy products category which ensures merely $10 \%$ of the monetary value [8]. However, seven FFV (fresh fruits and vegetables) categories consisting of apple, banana, grape, lettuce, pear, sweet pepper and tomato, which also known as "hotspot categories" usually contributed the majority share of wastage; both economically and in mass [19] (Table 5).

\begin{tabular}{|c|c|}
\hline High & Low \\
\hline Bakery (mainly bread and biscuits) & Ready-Made-meals Poultry Beef Seafood Lamb \\
\hline Fruits and berries Vegetables and potatoes & Cheese Fish Pork Confectionery \\
\hline
\end{tabular}

Source: Dreyer et al., 2018.

\section{Environmental Impact}

According to Swaffield et al., 2018, every ton of food waste has the potential to preserve 4.2 tons of carbon dioxide. The second highest position of carbon-di-oxide emission is 'Meat, seafood, dairy' and these foods are the main source for contributing almost $30 \%$ of carbon impact, 'Ready-made meals' and 'Fruits and vegetables', both categories have $10 \%$ carbon impact [8].

A report by the UN in 2011 stated that food across the chain is an international issue (FAO, 2011). Scientists, retail businesses and employees are simultaneously finding the relationship between food waste and environmental awareness. The environment can be affected by the discarded retail food waste, from $80.8 \%$ photochemical oxidation to $48 \%$ ozone layer consumption in junkyard, from $35.7 \%$ for global warming to $8.1 \%$ photochemical oxidation in incineration, from $12.9 \%$ for acidification to $4.9 \%$ for global warming in fertilizing, from $7.6 \%$ for freshwater aquatic ecotoxicity to $2.8 \%$ for global warming in anaerobic dissolution [21].

\section{Reasons of Retail Food Waste}

Reasons behind the retail food waste are mainly divided into different factors like perishability of food specially for fresh fruits and vegetables [23-26], employee fault [2,3,7,14, 27], influence of weather [5,27], Take-back agreement specially for bread and bakery $[15,16,28]$ and visual impairments [29]. Barriers to achieve a suitable food supply chain has also been discussed [12].

Difficulty in predicting sale causes food waste in retail. It can create over staking [5]. As food products get worse as time passes by, perishability of food products is a major concern in retail shops $[14,23,24,26]$. According to Mena et al. [23], core causes of waste generation was separated into three groups:

Trends: Marketplace trends such as demands for non-seasonal or fresh products affect this waste issue heavily.
Natural Causes: Product natures i.e. weather fluctuations or short shelf life influences the amount of waste.

Poor Management: Lack of forecasting or budgeting, improper packaging etc. have effects on waste generation.

According to Colombo de Moraes et al. [27], reasons of retail food waste can be ordered in six different genres: machine, method, labour, material, environment and measurements. Filimonau \& Gherbin, [7] mentioned five causes that prevent the motivation of food waste reduction in retail level. These are: Purchasing behavior and awareness of consumers, corporate policies (such as: bulk purchasing), irresponsible suppliers, employees fault and size of the supermarket. Consumer's demand for cheap food and increased competition of the retail level makes it difficult to introduce, apply and instruct the enhancement of sustainability in food supply chain. Globalization and haziness of food supply chain is the reason behind this issue [12].

\section{Prevention of Retail Food Waste}

Food waste can be reduced in different ways such as initiatives are taken by store holder $[5,13,15,24]$ economic losses produce motivation [19], Proper managerial interaction [7-9,20]. environmental concern makes it possible to reduce the amount of retail waste [11,21]. Implement laws and policies for proper handling this food waste $[2,7,12,15]$, proper packaging [18] and media attention [5]. Every day in Indonesia, selling limited amount of vegetables in the vicinity through mobile shops is quite popular [20]. Preservation of chilled products under less temperature is another way to reduce food wastage [5]. Changing policy is needed to show the guidelines of different actors in the supply chain or modify their commercial strategies to establish food waste reduction measures [15].

\section{Tackling Method of Surplus Retail Food}

Food waste that are generated by retailers can be managed in several ways, most of the authors suggested about donation and 
animal feed [7,10,11,13,23,29], landfill [11], food redistribution [29] and food recycle/recover [7,10]. Surplus foods should be distributed among the needy ones, used for poultry, animal feeds and send to landfill if it cannot be managed $[10,13]$. Edible portions can be given to charity or can be sold as pet food [23].

In New Zealand, $77 \%$ of all discarded retail food is diverted away from landfill to feed livestock. On the other hand, the UK and EU do not approve the wastage for animal feeding unless it's certified in healthy [11]. Nonmarketable or surplus foods are given to farmers, retailers and employees so that they can redistribute the food [29]. While in the case of food recovery, total 23.5 tons of food recovered. All these foods were completely fit for human consumption. The economic value of this recovered food was about €46,000 in Italy 2012 [3].

\section{Implementing Laws Regarding Retail Food Waste}

The policies of retail food waste reduction have been discussed in Mena et al., [23], Lanfranchi, et al., [25]; Hermsdorf et al., [29]; Swaffield et al., [13]; Gosh, et al., [16]; Rosenlund, et al., [5]. The suggestion for policymakers to improve sustainable food supply chain [12]. Some governmental initiatives [12] and nongovernmental initiatives have also been discussed [2].

EU Waste Framework Directive in 2008 introduced a standard "waste management hierarchy" and was included in UK laws [13]. The WRAP initiative (Water and Resources Action Programme) was formed in 2000 in UK and remains active. According to them, food waste in retail sector has now dropped around 10\% in between 2007 to 2015 (WRAP 2017, 2019).

The EU Council directive on Hazardous Waste (1991) was introduced across member states for strengthening the management of these materials. Other directives:

i. The EU Council Directive on Landfill (1999)

ii. $\quad$ The Packaging Waste Directive (1994)

iii. The Animal by products Directive (2000) [23,29]

The European Regulations CE No 1221/ 2008 that regulates the standards of grades of fruit and vegetables and permits the sale of less aesthetic goods [24]. Furthermore, in 2014 the European parliament proclaimed "European year against food waste" where the adopted resolution was to reduce $50 \%$ of waste by 2025 . According to BIO Intelligence Service 2009, categories of environmental initiatives depend on what kind of voluntary agreement it is carried on. This is varying from different suppliers. This type of agreement is usually applied at national level. For example- in Britain "Better Retailing Climate' and "Courtauld Commitment", these two agreements address packaging of food and waste issues. In Germany, a pilot stage project named"Product Carbon Footprint" has been implemented by calculating carbon footprint from different food products. In France, products are getting labelled according to environmental labels [12].
The EU might ban the practices of forcing the supplier to pay for wasted products" and "a buyer returning unsold food products to the supplier" [16]. France has developed a policy where retailers have to prioritize the division of surplus food, they are bound to give surplus food to charity and/or animal feedstock [10]. However, when surplus food is donated and accordingly free of charge for redistributors, the law of gifting policy applies (Articles 516-534, German civil code) [29].

\section{Decomposed Related Policies}

Sweden, along with many other European countries has banned landfilling of organic waste. Now less than $2 \%$ of total solid waste goes to landfill. Rest $98 \%$ are recycled, composted and digested [16]. According to FAO 2013, in 2010, the members of the Food and Drink Federation in the United Kingdom made a commitment to achieve the targets of food waste reduction and monitor the production of waste and shift it from landfill. Mainly the goal was to stop the landfilling system for dumping food waste by 2015 [2].

\section{Summary Findings of the Study}

Mostly the study area of reviewed papers was Europe and Scandinavian Countries. Only two papers were from the Asian continent. Those papers are Soma, 2019 (Indonesia) and Lee, 2017 (South Korea). These papers emphasized the impact of retail food waste on both economic and environmental sectors such as: Albizzati, et al., [10]; Dreyer et al., [8]; Marrucci, et al., [22]; Mattsson, et al., [19]. Amongst all these paper Marrucci et al., [22] discussed specifically about the carbon footprint from the waste of retail foods and packages. Sustainability of a retail food sector that forced back to achieve sustainable food retailing in Chkanikova and Mont, [12]. Categorization of retail food has been mentioned in Lebersorger and Schneider, [14]; Brancoli et al., [15]; Cicatiello et al., [3]; Cicatiello et al., [4]; Cicatiello et al., [9]; Eriksson et al., [17]; Eriksson et al., [6]; Filimonau and Gherbin [7], Ghosh and Eriksson [16], Goodman-Smith et al., [11]; Mattsson et al., [19]; Mondello, et al., [21]. Some of these papers focused individually on specific food items of retail level such as, Brancoli, et al., [15] discussed only bread waste in retail level. Whereas an article researched about the loss of fruits and vegetables [17,19].

Eriksson et al., [6] deals only with milk and dairy retail waste where they found that the dairy waste is mostly unrecorded because it's under the "Take back agreement" where sellers do not need to pay the unsold item. Albizzati et al., [11] took their study in surplus retail food. There are several suggestions that have been given on surplus food in Swaffield et al., [13]; Mena et al., [23]; Hermsdorf et al., [29]; Goodman-Smith et al., [11]; Filimonau, Gherbin [7]. Finally, the policies for retail food waste had been discussed in several papers such as Mena et al., [23], Lanfranchi, et al., [25]; Hermsdorf et al., [29]; Swaffield et al., [13]; Gosh, et al., [16]; Rosenlund, et al., [5]. All the policies are applicable in Europe mainly in the UK. 


\section{Scope of the Study}

The volumes and types of food waste generated in retail have been researched in the past. In Sweden and Switzerland as an example, however food loss in retail was competitively lower than other steps in the food chain [5]. The scholarly attention in retail level is limited in some repeating areas like Sweden, UK and mainly developed countries. However, there has been no study found regarding retail food waste in developing and poor countries like Bangladesh. Some studies must be done in Bangladesh, according to Chalak, et al., 2018 because of the inefficiencies of supply chain, food waste of the developing country has occurred at the initial level where in developed country this happened at the final level which is household or consumers' level. In a developing country, waste occurs in retail or supply chains more than consumer's waste.

\section{Proposed Framework for Encouraging Retail Food Waste Research}

Countries like Bangladesh, where population is dense, weather is humid and the distance between suppliers and consumers are scattered, so inadequate transportation is one of the main reasons for retail food waste. According to Chalak et al., 2018 mentioned that in developing countries the food waste mainly occurs in the initial stage of supply chain that means it is normal that a huge amount of food is being wasted before it goes to the customer's hand so the actual scenario of retail food waste must be acknowledged. But the reality is different, though several studies have been found about solid waste in Bangladesh, retail food waste is still overlooked not only by the government and NGO's, but also the education and research organizations as well. Here given a proposed framework that how it would be highlighted to academic network so that the studies will be conducted in near future about this topic.

The above framework (Figure 5) is proposed for enhancing the publication of retail food waste for the betterment of healthy food supply. The three interconnected discipline in this matter are implementing policies, research/education organization and monetary fund for doing research on retail food waste. These factors make a scope of different field of retail food waste and as a result, publication will be increased. In monsoon areas the foods are highly susceptible in microorganisms. From harvest to consumer plate, special care should be taken in every step. Otherwise, it will get rotten or visually impaired, to when the customers do not want to buy those foods. For improving the supply chain, research is mandatory for finding the best possible way to handle this. Developing research on retail food waste has successfully helped to save the food which is discarded before it become someone's feed whereas one in three people among the worldwide suffer from malnutrition (World economic forum, 2016). Collaboration between the Government and the NGOs has successfully accomplished this area.

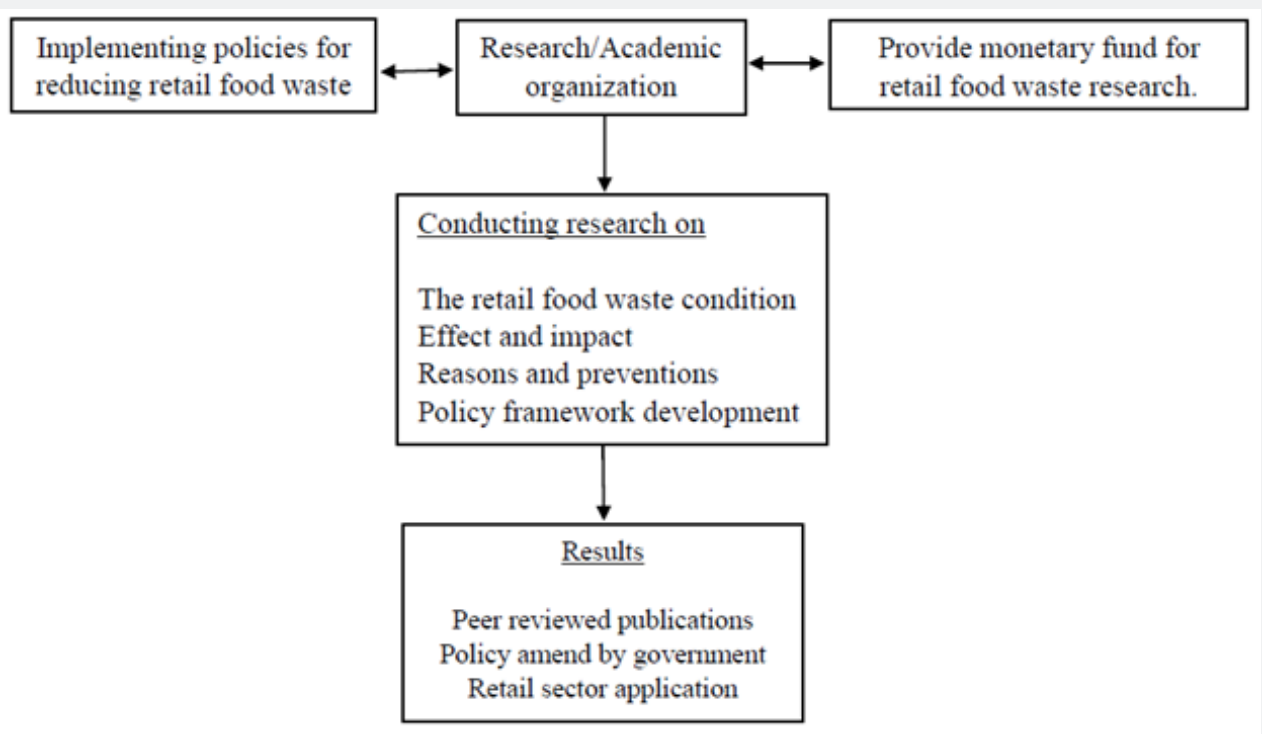

Figure 5: Framework for promoting retail food waste research.

\section{Conclusion and Recommendation}

This paper has reviewed the empirical, peer-reviewed studies on retail food waste situation and its waste generation characteristics and the factors that stimulate this waste. Overall we see the publication in this field is increasing day by day so it is clear that this topic grabs the attention amongst researchers. Though the concern of retail food waste is still less compared to other food waste in the supply chain, it is mentioned by various authors' because the portion of retail food waste from total food waste is very low. However, this is the only sector where reduction 
is effectively possible. To begin with this analysis that has shown owners or managers do not feel guilty about retail food waste, their predetermined mindset that some portion of food will have been wasted. Several studies demonstrate this intention but at the same time owners or managers are very conscious about economic loss, so they want to reduce the amount as much as possible.

It is clear from all papers that estimating the weightage of retail food waste is a complex matter. Because there is a unique term in retail named "unrecorded food waste". Few studies have been based on only "Take back agreement" which is the prime reason showed for unrecorded food waste. As take back agreement mainly applies in milk and bakery products, it would be tough to calculate mainly dairy food of the actual amount of waste which is being produced from the retail sector because this take back food is not recorded in the retail as waste because it has already returned.

A famous retail company in the UK revealed that every year they generated a huge amount of food waste. So, the food waste that is produced from this sector is not negligible. There are two types of adverse impact of retail food waste on economic and environmental sectors that have been raised. Fruits and vegetables dominate most of the part both value and mass. After fruits and vegetables bakery food grabs the second highest position in monetary loss. Likewise, in environmental impact this type of food generates some greenhouse gases like methane and carbon dioxide. Moreover, our analysis states that lack of knowledge regarding monetary and environmental effects carry this waste as a continuous process between retailers.

There are several reasons that have been shown for retail food waste. Retail food items need to be appealing because customers don't want to buy food with visible defects. So little faulty products are at risk to become waste. So visual acceptability is one of the main reasons for retail food waste. Although perishability is another reason for waste, highly perishable products are sensitive with weather fluctuation.

Furthermore, employees having improper knowledge of handling retail food is another reason for waste. There has been little research conducted on how proper training can reduce the retail waste. Few studies stated that realizing monetary loss and environmental loss between people and government can minimize the loss. Surplus food can be used as animal feedstock or given to needy people (if the food is completely edible). But the UK does not allow surplus food not only for the people but also for animal food. So, a huge amount of food is getting incinerated which is not good for the environment. One study has discussed about environment friendly decomposing methods of food waste. However, the most common method for decomposing food waste is incineration and anaerobic digestion. In the search of a solution, awareness should be built among the stakeholders and implement right policies are required for reducing this waste. Supportive customers are also needed to prevent this waste. Through advanced technology and natural scientific method, the sustainability of food is increasing day by day. So basic education is a must for those who are carrying the chain right now. Still, awareness is the main key to stop this waste. Besides proper knowledge about perishability, weather prediction, better storage system, information about each food item is also important to stop waste. Hence policy intervention can push this whole strategy one step ahead. When people are bound to do something, they automatically get aware.

This paper highlights various areas for further research. For a scholarly perspective, study on retail food waste is much more important in areas like Bangladesh. Because of the inadequate transportation, lack of laws and policies regarding retail food waste handling, use of preservative or ripening chemicals, and these three factors produce a noticeable amount of food waste in Bangladesh. So, the actual scenario should be revealed by analyzing this area. More study can help to expose the actual situation of this retail food waste region. So, after the study, government should interact with the policies according to the result.

Acknowledgment: "Finally, the authors are highly grateful to Bangabandhu Chair, Bangladesh University of Professionals for providing financial assistance of this research and publications".

\section{References}

1. Audet R, Brisebois E (2019) The Social Production of Food Waste at the Retail-Consumption Interface. Sustainability, 11, 3834.

2. Chalak A, Daher C, Abiad M (2018) Generation of food waste in the hospitality and food retail and wholesale sectors: lessons from developed economies. Food Secur 10: 1279-1290.

3. Cicatiello C, Franco S, Pancino B, Blasi E (2016) The value of food waste: An exploratory study on retailing. J Cleaner Prod 30: 96-104.

4. Cicatiello C, Franco S, Pancino B, Blasi E, Falasconi L (2017) The dark side of retail food waste: Evidences from in-store data. Resour Conserv Recycl 125: 273-281.

5. Rosenlund J, Nyblom A, Ekholm H, Sorme L (2020) The emergence of food waste as an issue in Swedish retail. Br Food J: 1-14.

6. Eriksson M, Strid I, Hansson PA (2014) Waste of organic and conventional meat and dairy products: A case study from Swedish retail. Resour Conserv Recycl 83: 44-52.

7. Filimonau V, Gherbin A (2017) An exploratory study of food waste management practices in the UK grocery retail sector. J Cleaner Prod 167: 1184-1194.

8. Dreyer H, Popovska I, Yu Q, Hedenstierna C (2018) A ranking method for prioritising retail store food waste based on monetary and environmental impacts. J Cleaner Prod 210: 505-517.

9. Cicatiello C, Franco S (2020) Disclosure and assessment of unrecorded food waste at retail stores. J Retail Consum Serv 52: 101932.

10. Albizzati P, Tonini D, Chammard C, Astrup T (2019) Valorisation of surplus food in the French retail sector: Environmental and economic impacts. Waste Manage 90: 141-151.

11. Goodman-Smitha F, Mirosaa M, Skeaf S (2020) A mixed-methods study of retail food waste in New Zealand. Food Policy 92: 101845.

12. Chkanikova O, Mont 0 (2012) Corporate Supply Chain Responsibility: Drivers and Barriers for Sustainable Food Retailing. Corp. Soc. Responsib. Environ. Mgmt 22(2): 65-82. 


\section{Annals of Social Sciences \& Management studies}

13. Swaffielda J, Evansb D, Welch D (2018) Profit, reputation and 'doing the right thing': Convention theory and the problem of food waste in the UK retail sector. Geoforum 89: 43-51.

14. Lebersorger S, Schneider F (2014) Food loss rates at the food retail, influencing factors and reasons as a basis for waste prevention measures. Waste Manage 34(11): 1911-1919.

15. Brancolia P, Lundina M, Boltona K, Eriksson M (2019) Bread loss rates at the supplier-retailer interface - Analysis of risk factors to support waste prevention measures. Resour Conserv Recycl 147: 128-136.

16. Ghosh R, Eriksson M (2019) Food waste due to retail power in supply chains: Evidence from Sweden. Glob Food Sec 20: 1-8.

17. Eriksson M, Strid I, Hansson PA (2012) Food losses in six Swedish retail stores: Wastage of fruit and vegetables in relation to quantities delivered. Resour Conserv Recycl 68: 14-20.

18. Gustavsson J, Stage J (2011) Retail waste of horticultural products in Sweden. Resour Conserv Recycl 55(5): 554-556.

19. Mattsson L, Williams H, Berghel J (2018) Waste of fresh fruit and vegetables at retailers in Sweden - Measuring and calculation of mass, economic cost and climate impact. Resour Conserv Recycl 130: 118126.

20. Soma T (2019) Space to waste: the influence of income and retail choice on household food consumption and food waste in Indonesia, International Planning Studies 1-21.

21. Mondello G, Salomone R, Ioppolo G, Saija G, Sparacia S, et al. (2017) Comparative LCA of Alternative Scenarios for Waste Treatment: The Case of Food Waste Production by the Mass-Retail Sector. Sustainability 9(5): 827.
22. Marrucci L, Marchi M, Daddi T (2020) Improving the carbon footprint of food and packaging waste management in a supermarket of the Italian retail sector. Waste Manage 105: 594-603.

23. Mena C, Adenso-Diaz B, Yurt O (2011) The causes of food waste in the supplier-retailer interface: Evidences from the UK and Spain. Resour Conserv Recycl 55(6): 648-658.

24. Hvolby HH, Steger-Jensen K (2015) Managing cannibalization of perishable food products in the retail sector. Procedia Comput Sci 64: 1051-1056.

25. Lanfranchi M, Giannetto C, Pascale A (2014) Analysis and model for the reduction of food waste in organized large-scale retail distribution in eastern Sicily. Am J Appl Sci 11(10): 1860-1874.

26. Lee KCL (2018) Grocery shopping, food waste, and the retail landscape of cities: The case of Seoul. J Cleaner Prod 172: 325-334.

27. Colombo de Moraes C, Henrique de Oliveira Costa F, Pereira C, Lago da Silva A, Delai I (2020) Retail food waste: mapping causes and reduction practices. J Cleaner Prod 256: 120124.

28. Erikssona M, Ghosh R, Mattssonc L, Ismatov A (2017) Take-back agreements in the perspective of food waste generation at the supplierretailer interface. Resour Conserv Recycl 122: 83-93.

29. Hermsdorf D, Rombach M, Bitsch V (2017) Food waste reduction practices in German food retail. Br Food J 119 (12): 2532-2546.

\begin{tabular}{l} 
Your next submission with Juniper Publishers \\
will reach you the below assets \\
- Quality Editorial service \\
- Swift Peer Review \\
- Reprints availability \\
- E-prints Service \\
- Manuscript Podcast for convenient understanding \\
- Global attainment for your research \\
- Manuscript accessibility in different formats \\
( Pdf, E-pub, Full Text, Audio) \\
- Unceasing customer service \\
Track the below URL for one-step submission \\
https://juniperpublishers.com/online-submission.php \\
\hline
\end{tabular}

